Louisiana State University

LSU Digital Commons

Faculty Publications

Department of Geography \& Anthropology

2011

\title{
How incipient colonies create territory: The textual surveys of New Spain, 1520s-1620s
}

Andrew Sluyter

Louisiana State University, asluyter@lsu.edu

Richard Hunter

Follow this and additional works at: http://digitalcommons.lsu.edu/geoanth_pubs

\section{Recommended Citation}

Sluyter, Andrew and Hunter, Richard, "How incipient colonies create territory: The textual surveys of New Spain, 1520s-1620s" (2011). Faculty Publications. 22.

http://digitalcommons.lsu.edu/geoanth_pubs/22

This Article is brought to you for free and open access by the Department of Geography \& Anthropology at LSU Digital Commons. It has been accepted for inclusion in Faculty Publications by an authorized administrator of LSU Digital Commons. For more information, please contact gcoste1@lsu.edu. 


\title{
How incipient colonies create territory: the textual surveys of New Spain, $1520 s-1620 s$
}

\author{
Richard Hunter $^{\mathrm{a}, *}$ and Andrew Sluyter ${ }^{\mathrm{b}}$ \\ ${ }^{a}$ Geography Department, State University of New York College at Cortland, 138 Old Main, Cortland, NY 13045-0900, United States \\ ${ }^{\mathrm{b}}$ Department of Geography and Anthropology, Louisiana State University, 227 Howe-Russell Geoscience Complex, Baton Rouge, LA 70803-4105, United States
}

\begin{abstract}
The study of colonial surveying and cartography has become key to understanding the history of European colonialism because of the recognition that land surveys and maps not only represent territory but form part of the process through which territory comes into being. While many studies have therefore focused on the history of instrumental surveying and cartography in New Spain, roughly equivalent to present-day Mexico, between the seventeenth and twentieth century, the textual surveys of the sixteenth century that helped to bring the initial colonial territory into being have gone largely unstudied. Content analysis of textual land surveys included in sixteenth-century viceregal land grants for sheep and cattle ranches demonstrates variation in references to distance, direction, and borders that begins to reveal a process of negotiation among local actors and centralized state power that was contingent on environmental, economic, and demographic differences between highland and lowland landscapes.
\end{abstract}

(c) 2011 Elsevier Ltd. All rights reserved.

Keywords: Mexico; Colonial period; Territory; Land surveying; Ranching; Content analysis

With the recognition that land surveys and maps not only represent territory but form 'part of the process by which territory becomes,' the effort to understand the emergence of colonial surveying and cartography has become key to understanding the history of European colonialism. ${ }^{1}$ In general, surveyors employed their specialized training in the use of instruments such as transits and compasses to take field measurements and convert them into cadastral and smaller-scale maps that made territory 'legible' to the colonial administration. ${ }^{2}$ The boundaries surveyors established, both abstractly on paper and concretely on the landscape with posts and other monuments, enabled 'places to appear and be named' so that settlers could establish who and where they were: 'the act of settling was not a matter of marking out pre-existing boundaries, but one of establishing symbolic enclosures. $^{3}$ As a social process that helped colonial territory come into being, surveying modulated the complex interactions among local actors, centralized state power, and specific landscapes. ${ }^{4}$

Recent research on colonial New Spain, now Mexico, has raised questions about how that process might have operated during the first century of colonization. The use of instruments to survey land and associated cadastral cartography emerged only in the 1630s, about a century after Hernán Cortés and the other conquistadors established the colony. ${ }^{5}$ Moreover, surveying went into decline in the first half of the nineteenth century, shortly after Mexico became politically independent from Spain. A variety of factors contributed to that late start and sudden decline, including the high cost of surveying, the latent boundary disputes that surveying tended to antagonize rather than resolve, and the upheaval of the revolutionary war in the 1810s and its aftermath. Meanwhile, research on land use during the Early Colonial Period (1521-1620) has revealed that despite the late start of instrumental surveying, the Spaniards

\footnotetext{
* Corresponding author.

E-mail addresses: richard.hunter@cortland.edu (R. Hunter), asluyter@lsu.edu (A. Sluyter).

1 J.B. Harley, Rereading the maps of the Columbian encounter, Annals of the Association of American Geographers 82 (1992) $522-536$.

2 J.C. Scott, Seeing like a State: How Certain Schemes to Improve the Human Condition have Failed, New Haven, 1998.

3 P. Carter, The Road to Botany Bay: an Essay in Spatial History, London, 1987, 158, 168.

${ }^{4}$ R.B. Craib, Cartographic Mexico: a History of State Fixations and Fugitive Landscapes, Durham, 2004; J. Jacobs, Edge of Empire: Postcolonialism and the City, London, $1996,158$.

${ }^{5}$ M. Aguilar-Robledo, Contested terrain: the rise and decline of surveying in New Spain, 1500-1800, Journal of Latin American Geography 8 (2009) 23-47.
} 
were nonetheless able to distribute much land during the first century of colonization. ${ }^{6}$

While many aspects of surveying and cadastral cartography during the seventeenth through twentieth century have received attention, the sixteenth-century surveying that helped to bring the initial colonial territory into being has gone largely unstudied and remains only generally understood. ${ }^{7}$ Spaniards and, to a lesser extent, native communities received viceregal land grants known as mercedes for sheep ranches (sitio de estancia para ganado menor, hereafter sheep estancia) and cattle ranches (sitio de estancia para ganado mayor, hereafter cattle estancia). They also received mercedes for farmland, lime kiln sites, inns, and other land uses. In general, the viceregal government brought those land parcels into being within the larger colonial territory by relying on non-specialized local officers who inspected each land grant and produced a textual survey of its location. Those incipient surveyors did not require specialized training in geometry, use of instruments such as transits and compasses, or translation of field measurements into cadastral maps. Instead, the general skills involved included an ability to read the landscape, estimate distance and direction, and write the survey report.

Similar, and similarly understudied, phases of textual surveying are evident during the colonization of other parts of the Americas by the Spaniards, French, and British during the sixteenth through eighteenth centuries. The land grants made at the founding of Buenos Aires in 1580 and for half a century thereafter relied on textual descriptions. ${ }^{8}$ Land grants in Louisiana during the French period include textual surveys similar to those of New Spain; not until the Spanish period, in the late eighteenth century, do instrumental surveys and property maps begin to appear. ${ }^{9}$ The same situation prevailed in British colonies such as Virginia and Jamaica during the seventeenth century. ${ }^{10}$ In contrast, instrumental surveying dominated the subsequent eighteenth- and nineteenthcentury colonization of other regions, including much of Africa, New Zealand, and so on. ${ }^{11}$
The Mercedes Section of the Archivo General de la Nación (AGN) in Mexico City preserves the vast majority of the mercedes of New Spain. ${ }^{12}$ When those textual surveys proved inadequate to prevent boundary disputes, the courts sometimes ordered a cartographic rendering to better understand the dispute and reach a verdict. ${ }^{13}$ The Tierras Section of the AGN preserves many of those maps and other court documents. The research that has drawn on those documents thus far has mainly used them to understand earlycolonial land use and its environmental consequences. ${ }^{14}$ None of those studies has focused specifically on understanding the actual act of surveying involved in the emergence of colonial landscapes compartmentalized into plots linked to the identities of specific settlers.

The study of sixteenth-century surveying must employ different methods than those appropriate to the study of the instrumental surveying that began in the 1630s. Studies of the later period can examine a suite of instruments such as compasses and transits, instruction manuals, professional schools, and cartographic techniques. ${ }^{15}$ An investigation into the earliest period of surveying must, in contrast, execute a textual analysis of the mercedes. Such content analysis of the texts of a large number of mercedes for estancias should reveal patterns that demonstrate how surveying varied in relation to environmental differences such as highland versus lowland, economic differences such as sheep versus cattle ranching, and demographic differences such as dense native settlement versus sparse native settlement. ${ }^{16}$ While viceroys issued colony-wide ordinances as if such variations were immaterial, other studies have demonstrated their impacts on the construction of colonial territory, as in the case of the coastal lowlands versus the Andean highlands of the Viceroyalty of Granada, now Colombia. ${ }^{17}$ Such variations begin to reveal the interactions between bureaucrats and particular peoples and places through which colonial space came into being, resulting in both landscape transformations and the accumulation of an archive of spatial knowledge that became central to establishing land ownership then and for

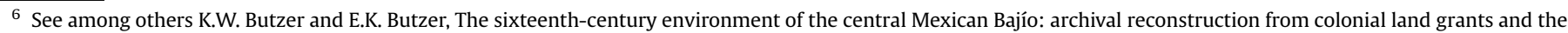

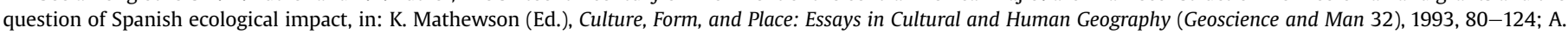

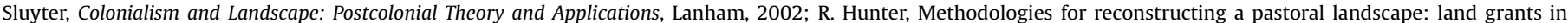
sixteenth-century New Spain, Historical Methods 43 (2010) 1-13.

7 See among others Craib, Cartographic Mexico (note 4); R.B. Craib, The archive in the field: document, discourse, and space in Mexico's agrarian reform, Journal of Historical

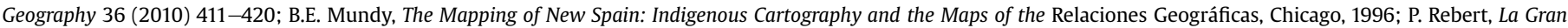
Linea: Mapping the United States-Mexico Boundary, 1849-1857, Austin, 2001; Aguilar-Robledo, Contested terrain (note 5).

8 Archivo Histórico de la Provincia de Buenos Aires, La Plata, Argentina, Libro de Mercedes de Tierras, $1580-1635$.

9 Tulane University, Special Collections, New Orleans, Louisiana, Louisiana Land Grants, 1753-1769; Louisiana State University, Baton Rouge, Special Collections, Lower Mississippi Valley Collections, especially the Carlos Trudeau Papers, Pintado Papers, and Survey Collection.

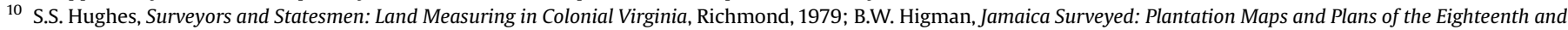
Nineteenth Centuries, Kingston, 2001.

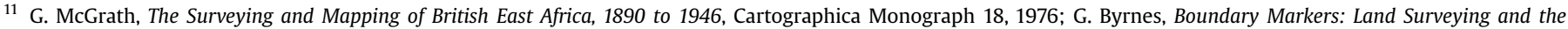
Colonisation of New Zealand, Wellington, 2001.

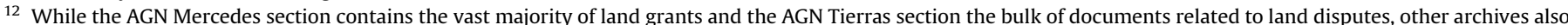

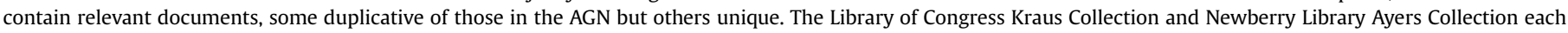

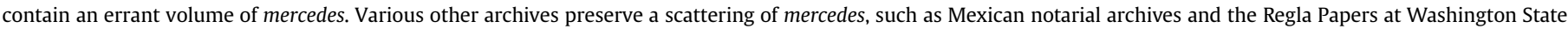
University, Pullman, Manuscripts, Archives, and Special Collections.

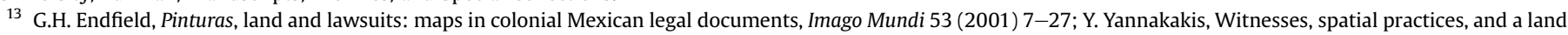
dispute in colonial Oaxaca, The Americas 65 (2008) 161-192.

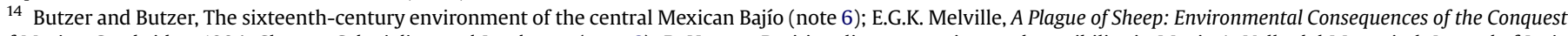

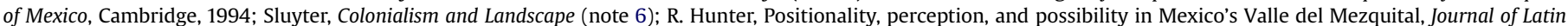
American Geography 8 (2009) 49-69; Hunter, Methodologies for reconstructing a pastoral landscape (note 6).

15 Craib, Cartographic Mexico (note 4); Craib, The archive in the field (note 7); Aguilar-Robledo, Contested terrain (note 5).

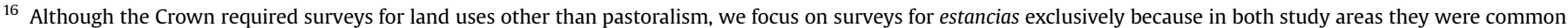

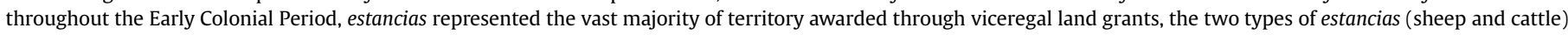

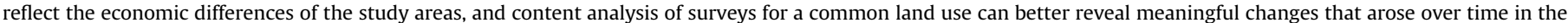
act of surveying.

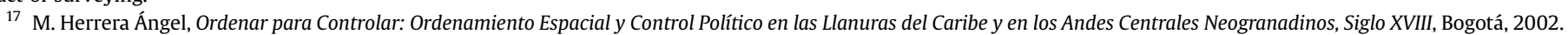




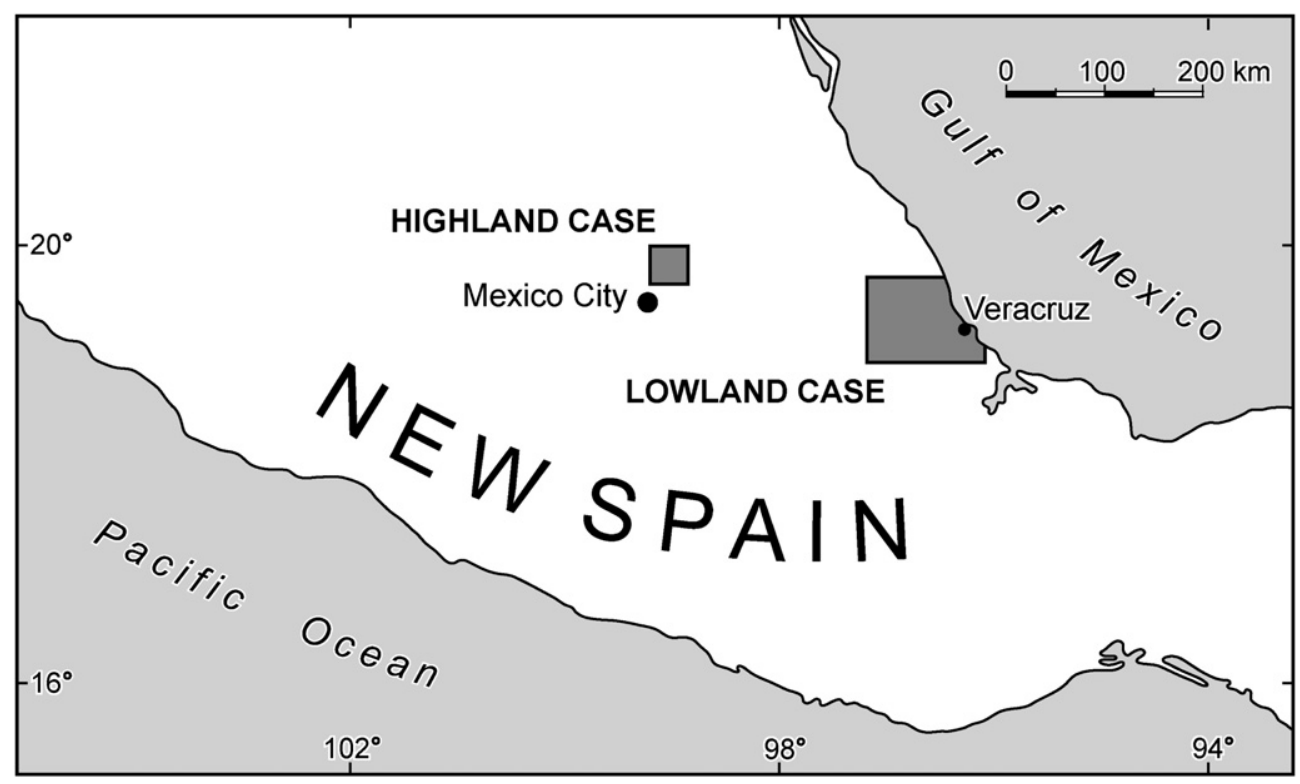

Fig. 1. New Spain and the locations of the highland and lowland cases.

centuries thereafter, until the agrarian reform of the twentieth century. $^{18}$

\section{Land grants in lowlands and highlands}

Analysis of surveys from regions with different environmental, economic, and social contexts should reveal insights into how surveying varied across the colony. Towards that end, the mercedes for this study derive from two distinct regions of New Spain, the coastal lowlands along the Gulf of Mexico near the port of Veracruz and an area of the central highlands just north of Mexico City (Fig. 1). The lowland case involves some $5000 \mathrm{~km}^{2}, 149$ mercedes awarded between 1541 and 1617, a sub-humid tropical lowland, and a preponderance of cattle estancias. ${ }^{19}$ The highland case involves about $600 \mathrm{~km}^{2}, 44$ mercedes awarded between 1542 and 1610 , a semi-arid tropical highland, and only sheep estancias. ${ }^{20}$ In the precolonial era the highlands supported higher population densities than the lowlands and the highlands' native population did not suffer as severe a decline during colonization. Because of New Spain's diverse (pre)colonial social contexts, it is unlikely that all highlands and all lowlands would reflect the same variations in surveying that these two particular cases exhibit.

Both cases involved the same general process of land granting. In function, a merced was the final document in the granting process. $^{21}$ The legal process began with a request to the viceroy for a grant and a subsequent viceregal response: the mandamiento acordado, many of which are preserved in the Mercedes and Tierras sections of the AGN. The mandamiento acordado ordered an inspection by a designated local Crown officer to ensure that the grant under consideration would not prejudice the interests of the Crown or third parties such as natives and adjacent land owners. An example illustrates.

On this day [30 June 1565] a mandamiento acordado was issued for the alcalde mayor of Veracruz, in due time, to inspect a sitio de estancia for mares requested by Juan Núñez de Montalván, citizen of Veracruz. ${ }^{22}$

The officer then carried out the inspection and submitted a recommendation for or against the merced, as supported by depositions of third parties. In form, the typical merced contained opening and closing formulas which concerned the authority of the Crown and the obligations of the grantee. Those formulas follow royal decrees, codified in 1618 as the Recopilación de Leyes de los Reinos de las Indias, prohibiting land speculation, damage to native interests, and subsequent sale to the church. ${ }^{23}$ The viceroy charged no fees to initiate or finalize that process until the 1590s when a payment of a quarter of the assessed value began to apply. ${ }^{24}$

The archives preserve the full set of documents related to several grants in the highland and lowland cases, one of which serves as a detailed example of the process. ${ }^{25}$ On 19 January 1617 , Viceroy Diego Fernández de Córdoba directed a mandamiento acordado to the local officer in La Antigua Veracruz to inspect a request by Luis Ochoa for four sheep estancias. The mandamiento acordado described the proposed sites in detail and specified that the officer should immediately post the order in the town of La Antigua Veracruz, inspect the sites within

\footnotetext{
18 Craib, The archive in the field (note 7).

19 Sluyter, Colonialism and Landscape (note 6).

${ }^{20}$ Hunter, Methodologies for reconstructing a pastoral landscape (note 6).

21 F. Chevalier, Land and Society in Colonial Mexico: the Great Hacienda, Berkeley, 1963, 57; H.J. Prem, Spanish colonization and Indian property in central Mexico, 1521-1620,

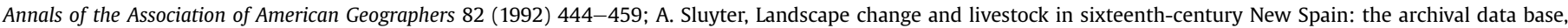

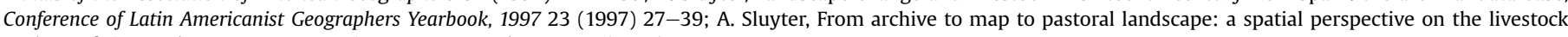
ecology of sixteenth-century New Spain, Environmental History 3 (1998) 508-528.

22 Archivo General de la Nación, Mexico City, Mexico, Mercedes Vol. 8, f. 58v. [hereafter AGN Mercedes]. All translations from the original Spanish by the authors.

23 Recopilación de Leyes de los Reinos de las Indias, 5 Vols. Mexico City, 1987, book 4, title 12.

24 H.J. Prem, Milpa y Hacienda: Tenencia de la Tierra Indígena y Española en la Cuenca del Alto Atyoac, Puebla, México 1520-1650, Mexico, 1988, 122.

25 Archivo General de la Nación, Mexico City, Mexico, Tierras Vol. 2784, pt. 1, exp. 3 [hereafter AGN Tierras]; AGN Mercedes Vol. 33, ff. 114-115v.
} 


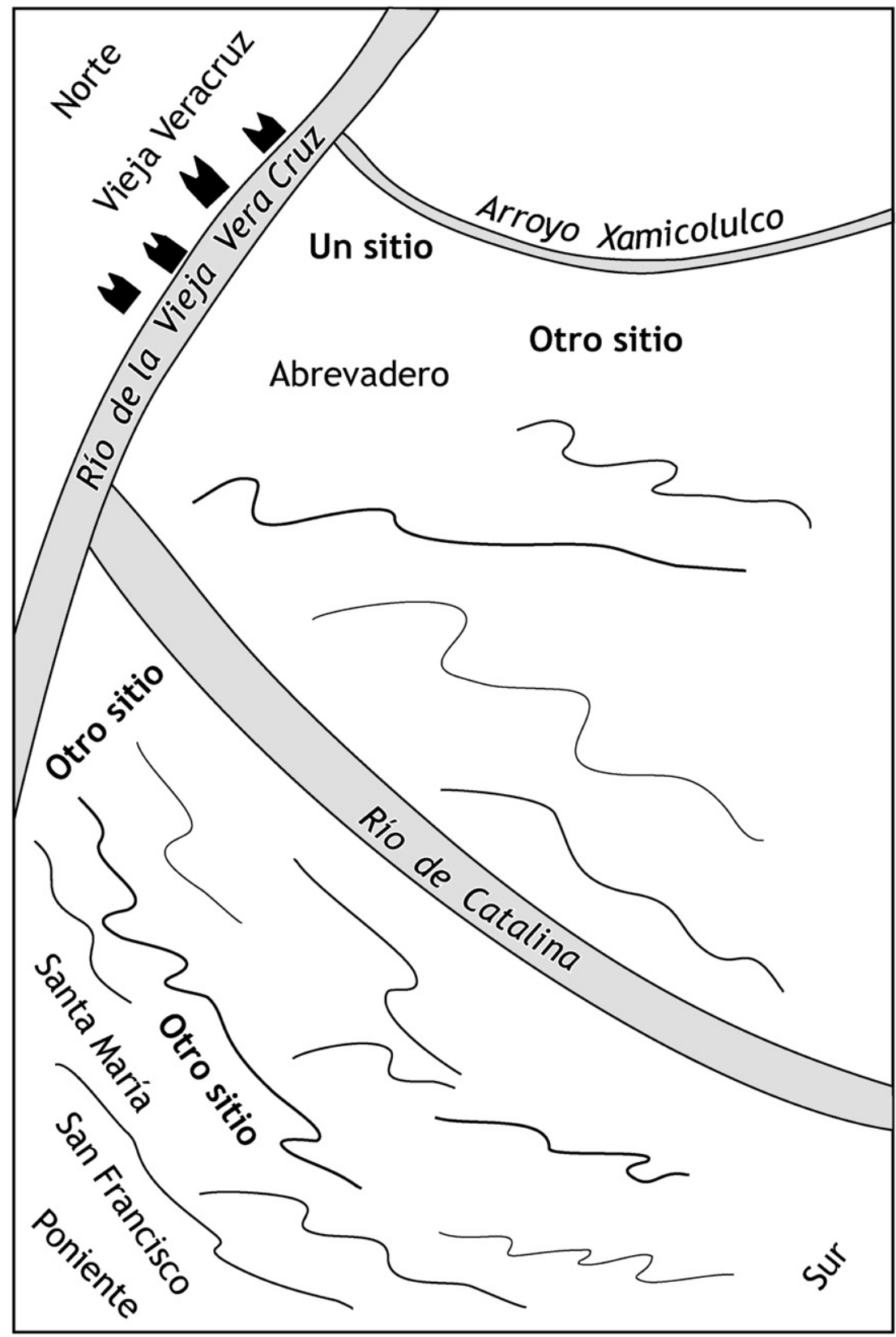

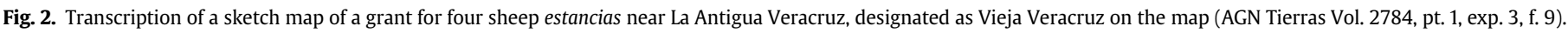
Compare to Craib, The archive in the field, map 2.

a month accompanied by any neighboring land owners and the leaders of nearby native communities, take their depositions regarding conflicts of interest, and allow any such third party four months from the date of posting to register any objections. On 8 February, the officer's lieutenant in fact did post a copy of the mandamiento acordado on the door of the town's church. On 13 February, the lieutenant, his scribe, and several third parties inspected the proposed sites and visited the surrounding settlements and estancias. The scribe recorded the depositions of a series of Spanish and native witnesses, and on 30 June the local officer, having waited the stipulated four months, wrote a report recommending that the viceroy award the grant. He even included a map of the locations, albeit a rough sketch compared to the instrumentally surveyed cadastral maps that were to become common in subsequent centuries (Fig. 2). And finally, on 7 July, the viceroy accepted that recommendation and granted the four estancias to Luis Ochoa.

The terminology defining units of measure that appear in the surveys and the conceptual territory represented by each estancia has long remained problematic. References to leguas might be to the legua común of $5.6 \mathrm{~km}$ or the legua legal of $4.2 \mathrm{~km}^{26}$ Similarly, references to pasos might be to the paso

\footnotetext{
${ }^{26}$ R. Chardon, The linear league in North America, Annals of the Association of American Geographers 70 (1980) 129-153.
} 

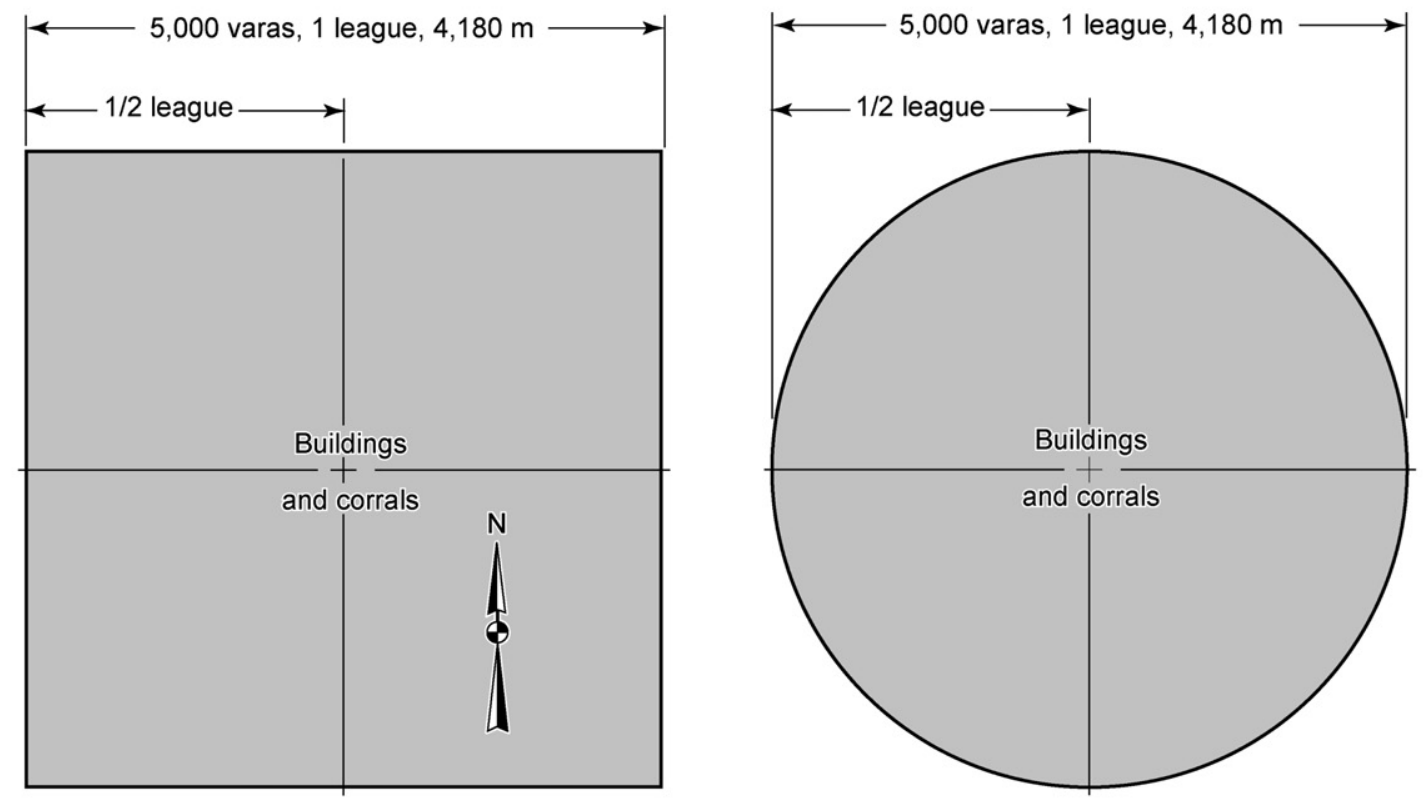

Fig. 3. Alternative conceptualizations of the estancia for large stock.

ordinario of $0.6966 \mathrm{~m}$ rather than the legal paso geométrico of $1.3926 \mathrm{~m}$, which was the vara de medir antigua (also known as the paso de marca or paso de Salomón) as opposed to the vara (also known as the vara de Castilla, vara de Burgos, or vara de medir). ${ }^{27}$ The tiro de arcabuz (musket shot) remains the most mysterious unit.

Moreover, some colonial administrators conceptualized estancias as circles and others as squares (Fig. 3). Various documents use the circular alternative, with the corrals and other structures at the center. ${ }^{28}$ The most credible support for that circular form comes from the 10 June 1589 testimony of Juan de Cueva, New Spain's chief scribe during the 1585-1590 tenure of Viceroy Alvaro Manrique de Zúñiga. ${ }^{29}$ The square alternative nonetheless seems to have prevailed, with viceregal ordinances by Antonio de Mendoza in 1536, Gastón de Peralta in 1567, and Martín Enríquez de Almansa in 1574 and 1580 specifying north-south oriented squares. ${ }^{30}$ The grants for various other types of land uses also had square plans, ranging from the 776 ha for an estancia for small stock to the fraction of a hectare for plots to build inns and mills (Table 1). The rectangular agricultural plot of 43 ha provided the only exception.

\section{Land surveyors}

The surveyors were not among the colony's elite. That elite consisted of the encomenderos, the holders of grants of native tribute and labor. This social group consisted of the conquistadors who overthrew the Aztecs in 1521 and received encomiendas for that service to the Crown, and those settlers who had arrived after 1521 (pobladores) but married into the families of the conquistadors. When a conquistador who held an encomienda died, his widow inherited it. Pobladores who married those encomenderas could themselves become encomenderos by marriage and their children by inheritance.

The encomienda served as the colony's 'master institution' until the 1550s, loosely simulating the political, economic, and settlement patterns that the Spaniards had usurped from the Aztecs. ${ }^{31}$ It encompassed the primary flux of capital and labor; it articulated the power of the state; and it interfaced between natives and nonnatives. As reward for taking part in the conquest of New Spain, the encomendero received license to exploit the natives settled in a particular place for a specific period in return for Christianizing the natives under his guardianship. Two persistent trends brought

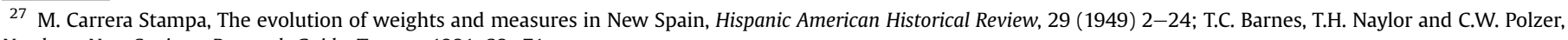
Northern New Spain: a Research Guide, Tucson, 1981, 68-71.

28 AGN Tierras Vol. 2672, exp. 8, f. 21, Vol. 2764, exp. 17, f. 223, Vol. 3185, exp. 2, ff. 62-63v.

29 AGN Tierras Vol. 3460, exp. 2, ff. 10-14v.

30 M. Galván, Ordenanzas de Tierras y Aguas, Mexico, 1851, 123-141; Sluyter, Colonialism and Landscape (note 6), 83-85.

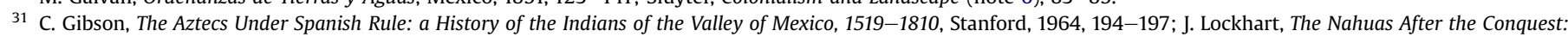

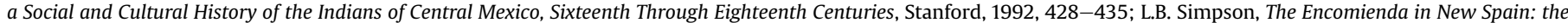

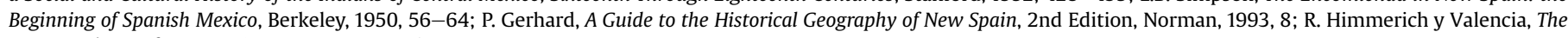
Encomenderos of New Spain, 1521-1555, Austin, 1991, 15-17.
} 
Table 1

Types of land grants.

\begin{tabular}{|c|c|c|c|c|c|c|}
\hline Grant type & Plan & Orientation & Size (varas) & Size $(\mathrm{m})$ & Area (ha) & Stocking rate (head) \\
\hline Ganado mayor & Square & North-south & $5000 \times 5000$ & $4180 \times 4180$ & 1747 & 500 \\
\hline Ganado menor & Square & North-south & $3333.3 \times 3333.3$ & $2786 \times 2786$ & 776 & 2000 \\
\hline Caballería de tierra & Rectangle & - & $1104 \times 552$ & $923 \times 461$ & 43 & - \\
\hline Solar para casa & Square & - & $50 \times 50$ & $42 \times 42$ & 0.18 & - \\
\hline Plot for venta & Square & - & $50 \times 50$ & $42 \times 42$ & 0.18 & - \\
\hline Plot for ingenio & Square & - & $50 \times 50$ & $42 \times 42$ & 0.18 & - \\
\hline Plot for molino & Square & - & $50 \times 50$ & $42 \times 42$ & 0.18 & - \\
\hline
\end{tabular}

the encomienda system to a nominal close around mid-century and to virtual extinction by 1600 . First, as the native population declined in a series of devastating epidemics, tribute revenue also declined. Second, as the Spanish state consolidated power, the focus of capital accumulation shifted from tribute to silver mining. Regular troops replaced conquistadors and native labor became required for mining and infrastructure construction. Encomenderos thus became a liability and an object of state suppression.

The local officers invested with viceregal authority to inspect and survey land grants carried the title of either corregidor or alcalde mayor and were mainly pobladores who had not become encomenderos or, later in the century, creoles, those colonists born in New Spain. The Crown drew these officers from the professional class of Spaniards in the jurisdictions they would oversee. A corregidor functioned as a magistrate, constable, and tribute collector in a district of native settlements. Among Spanish settlements an alcalde mayor performed many of the same duties as a corregidor, and frequently the same person held both offices. ${ }^{32}$ Unlike encomenderos, these officers primarily belonged to a social group involved in the second phase of colonization. In the lowland case 137 of the 149 mercedes for estancias include a legible officer's name and in the highland case 34 of the 44 mercedes include a legible name. Of those for whom adequate biographies are available (27 of 74), each was either a poblador or a creole (Table 2). Most of these were pobladores, reflecting both a high influx of immigrants as well as an entrenched social hierarchy that privileged colonists born in the metropole above all others. An officer's tenure typically lasted fewer than five years and inspecting land grants was an irregular duty. Fifteen of the 52 known officers in the lowlands, and only two of the 22 in the highlands, conducted more than two inspections of estancias. Officers in the lowlands conducted more inspections on average, likely reflecting the larger granting jurisdictions in this area.

These second-phase colonists were landed gentry motivated by land accumulation and business rather than simply tribute collection. Nearly a fifth of the officers who surveyed estancias in the two case areas themselves received mercedes for estancias (see Table 2). They and other officers also received mercedes for lime kilns and farmland, among other land uses, and purchased mercedes. ${ }^{33}$ The Ruiz de Códova family exemplifies this process. The family's patriarch, Gonzalo Ruiz de Córdova, was a merchant who immigrated to New Spain by 1535 and later served as a lieutenant for the alcalde mayor of Veracruz inspecting land grants. ${ }^{34}$ From 1547 to 1593, between father Gonzalo and sons Hernando and Gaspar, the Ruiz de Córdovas personally received mercedes for twelve cattle estancias and one sheep estancia. ${ }^{35}$ They also purchased estancias, Gonzalo receiving a dispensation in 1558 to purchase an estancia from a woman who had inherited it when her son died. ${ }^{36}$

Further, these second-phase colonists operated within a network of prominent local landholders who requested grants, inspected and surveyed them, and frequently provided sworn testimony when a native community objected to one of their grant requests. As an illustration from the highland case, in 1563 the viceroy awarded a sheep estancia to Andres de Estrada, the son of a conquistador. ${ }^{37}$ In that same year the natives of Tlapanaloya informed the viceroy that sheep belonging to Alonso de Aranda, the son-in-law of a conquistador, damaged their agricultural fields and the trees that provided them with firewood to fuel their lime kilns. ${ }^{38}$ In 1580 both Andres de Estrada and Alonso de Aranda testified in support of Alonso de Mansilla's request to build a lime kiln near Tlapanaloya. The town's natives, who themselves produced and sold lime to pay their tribute, objected to Mansilla's request on the grounds that this kiln would deplete their supply of firewood. The alcalde mayor who presided over the case ruled against the natives. ${ }^{39}$ At different times Andres de Estrada, Alonso de Aranda, and Alonso de Mansilla all held the office of either corregidor or alcalde mayor. ${ }^{40}$

\section{Analysis of textual surveys}

The use of standardized locational and geometric elements distinguishes the instrumental surveys that began in the 1630 s from the earlier textual surveys. Although viceregal ordinances required surveyors to lay out estancias as square parcels, most sixteenth-century surveyors failed to even attempt to describe such an idealized geometry. Instead they provided general locational descriptions in relation to natural and cultural landscape features to describe the general area of an estancia because the local natives, settlers, and others would be able to recognize those landmarks. Surveyors frequently described an estancia's location in

\footnotetext{
32 Gerhard, A Guide to the Historical Geography of New Spain (note 31), 14.

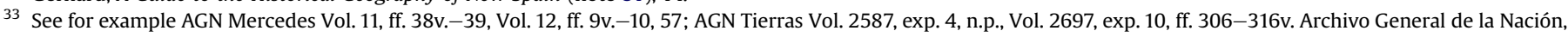
Mexico City, Mexico, Indios Vol. 5, exp., ff. 940, 241v.-242.

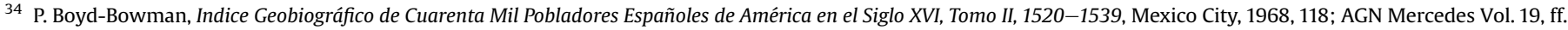
48-49.

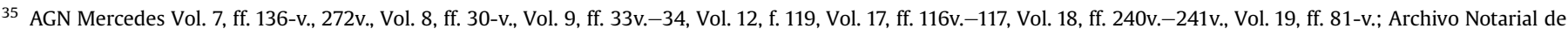
Xalapa, Xalapa, Veracruz, Mexico, Protocolo Vol. 1600-1608, ff. 414-415v. [hereafter ANX Protocolo].

36 ANX Protocolo Vol. 1600-1608, f. 415v.; G. Bermúdez Gorrochotegui, El Mayorazgo de la Higuera, Xalapa, $1987,77$.

37 AGN Mercedes Vol. 6, f. 205.

38 AGN Mercedes Vol. 7, f. 111; AGN Tierras Vol. 2697, exp. 11, f. 319.

39 AGN Tierras Vol. 2697, exp. 10, ff. 306-316v.

40 AGN Mercedes Vol. 8, f. 89, Vol. 15, ff. 161-v., Vol. 21, ff. 80v.-81.
} 
Table 2

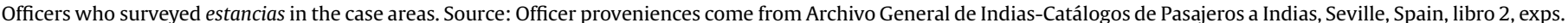

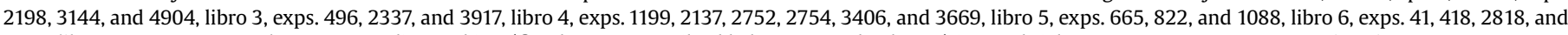

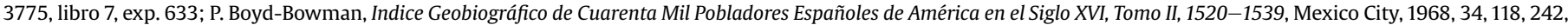

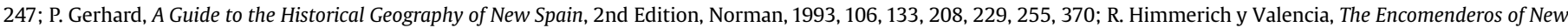

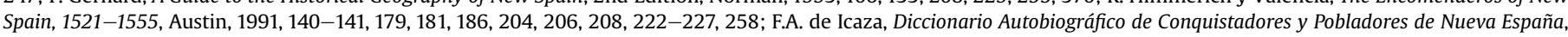
Madrid, 1923, Vol. 1, 164-165, 168-169, Vol. 2, 113-114, 620; A. Sluyter, Colonialism and Landscape: Postcolonial Theory and Applications, Lanham, 2002, 129-130.

\begin{tabular}{|c|c|c|c|c|c|c|c|}
\hline Case area & $\begin{array}{l}\text { Known officers who } \\
\text { surveyed estancias }\end{array}$ & $\begin{array}{l}\text { Surveys by known } \\
\text { officers }\end{array}$ & $\begin{array}{l}\text { Average surveys } \\
\text { performed }\end{array}$ & $\begin{array}{l}\text { Most surveys by a } \\
\text { single officer }\end{array}$ & $\begin{array}{l}\text { Officers awarded } \\
\text { estancias }\end{array}$ & $\begin{array}{l}\text { Known } \\
\text { pobladores }\end{array}$ & $\begin{array}{l}\text { Known } \\
\text { creoles }\end{array}$ \\
\hline Lowland & 52 & 137 & 2.6 & 8 & 9 & 19 & 4 \\
\hline Highland & 22 & 34 & 1.5 & 5 & 4 & 3 & 1 \\
\hline
\end{tabular}

relation to adjoining or nearby landscape features, and almost always in conjunction with the use of 'spatial prepositions. ${ }^{41}$ These include 'near,' 'next to,' and 'between' to describe the spatial relationship between an estancia's location and the surrounding landscape features. A fairly typical survey in this respect derives from the lowlands where a proposed site for an estancia rested three musket shots from the coast of the northern sea [the Gulf of Mexico], between the city of Veracruz and the Río de Medellín, next to a large river of freshwater named Río Grande that flows into the sea, between the Moreno estancia and the said city. ${ }^{42}$ The lack of training, equipment, and experience aside, before mid-century surveyors would have had little incentive to be more precise. Indeed, precise locational descriptions may have been of little concern to close-knit groups of local land owners and Crown officers. Only in the 1560 s, as a boom in land granting began to fill the landscape and boundary disputes became common, did surveyors begin to employ more standardized locational and geometric elements such as uniform units of measurement, cardinal directions, and boundary alignments.

Content analysis of temporal and geographic variation in the use of such surveying elements compares the frequency of their appearance in the mercedes for the highland and lowland cases. The difference in the number of mercedes awarded in each of the two cases precludes a direct comparison of the absolute number of references to surveying elements. Instead, comparison of change over time in the percentage of mercedes that contain references to each element reveals some striking differences between highlands and lowlands. Surveys prepared by experienced and inexperienced officers are indistinguishable in terms of their length and quality. For example, in the lowlands between 1594 and 1595 corregidor Francisco Martel completed eight surveys, more than any other officer in either study area, and they reflect no improvement that might have come from experience. ${ }^{43}$ Apparently, each officer composed surveys guided by a suite of widely accepted practices that did not evolve materially during his brief tenure in office.

\section{Distance}

Surveyors referenced almost exclusively just three units of distance: the vara, the paso, and the legua. Of these, the legua is by far the most common unit of distance that appears in the textual surveys. While each of these three units had variable lengths, those differences may have been of more theoretical than practical importance because surveyors tended to measure distances imprecisely. Regulations required surveyors to measure distances with a cord either 50 or 100 varas long, but surveyors typically relied upon their best estimates of distance or traveled to the proposed site on muleback; they presumed that a mule walking for an hour covered one league. ${ }^{44}$

The highland and lowland cases present quite different accounts of how surveyors incorporated units of distance into their textual descriptions. Forty-eight of the 149 mercedes for estancias awarded in the lowlands employ a unit of distance. Only eight of the highlands' 44 mercedes for estancias do so. This discrepancy means that the percentage of mercedes in the lowlands that reference units of distance sits 10-20\% higher than in the highlands on an annual basis (Fig. 4). Moreover, the references to units of distance in the lowlands' mercedes are commonly for lengths of four, five, and six leagues. ${ }^{45}$ Yet in the highlands' mercedes the longest distance that appears is one reference to two leagues. ${ }^{46}$

In part this difference relates to the different settlement patterns of the two cases. The viceroys of New Spain awarded estancias within the jurisdictions of the principal indigenous towns (cabeceras). During the sixteenth century these jurisdictions largely reflected the precolonial political landscape. ${ }^{47}$ In precolonial times the highland case study area was much more densely settled than the lowland case study area and this area had a relatively large number of cabeceras for its size. Consequently, cabeceras in the highlands had rather small jurisdictions, especially in comparison to the jurisdictions of the cabeceras in the lowlands. ${ }^{48}$ And grant surveyors based in those cabeceras would therefore invariably be closer to them when describing the location of an estancia relative the cabecera in the highlands than in the lowlands. Grants for the lowlands and highlands illustrate the point:

For the lowland case: [M]erced to Pedro de Castañeda y León of two sitios de estancia para ganado mayor....in the limits of the jurisdiction of the city of Veracruz, the one about two leguas, a little more or less, from the city...., and the other about three leguas from the said city. ${ }^{49}$

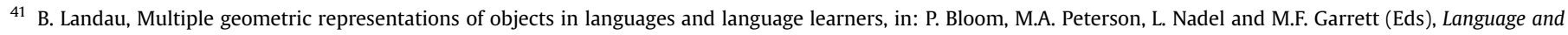

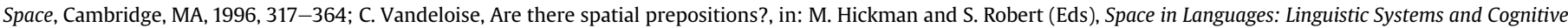
Categories, Amsterdam, 2006, 139-154.

42 AGN Mercedes Vol. 13, ff. 40-v.

43 AGN Mercedes Vol. 20, ff. 36-v., 144-145, Vol. 21, ff. 6v.-8, 47-48v.; AGN Tierras Vol. 2702, exp. 13, ff. 398-406v.

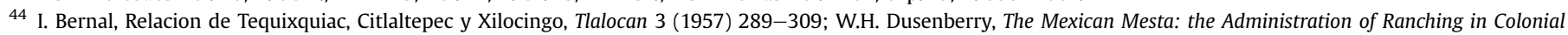
Mexico, Urbana, 1963, 99.

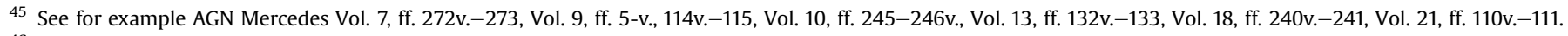

46 AGN Mercedes Vol. 23, ff. 113-v.

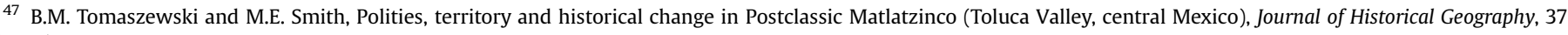
(2011) 22-39.

48 Gerhard, A Guide to the Historical Geography of New Spain (note 31), 295-300, 363-367.

49 AGN Mercedes Vol. 12, ff. 118-v.
} 


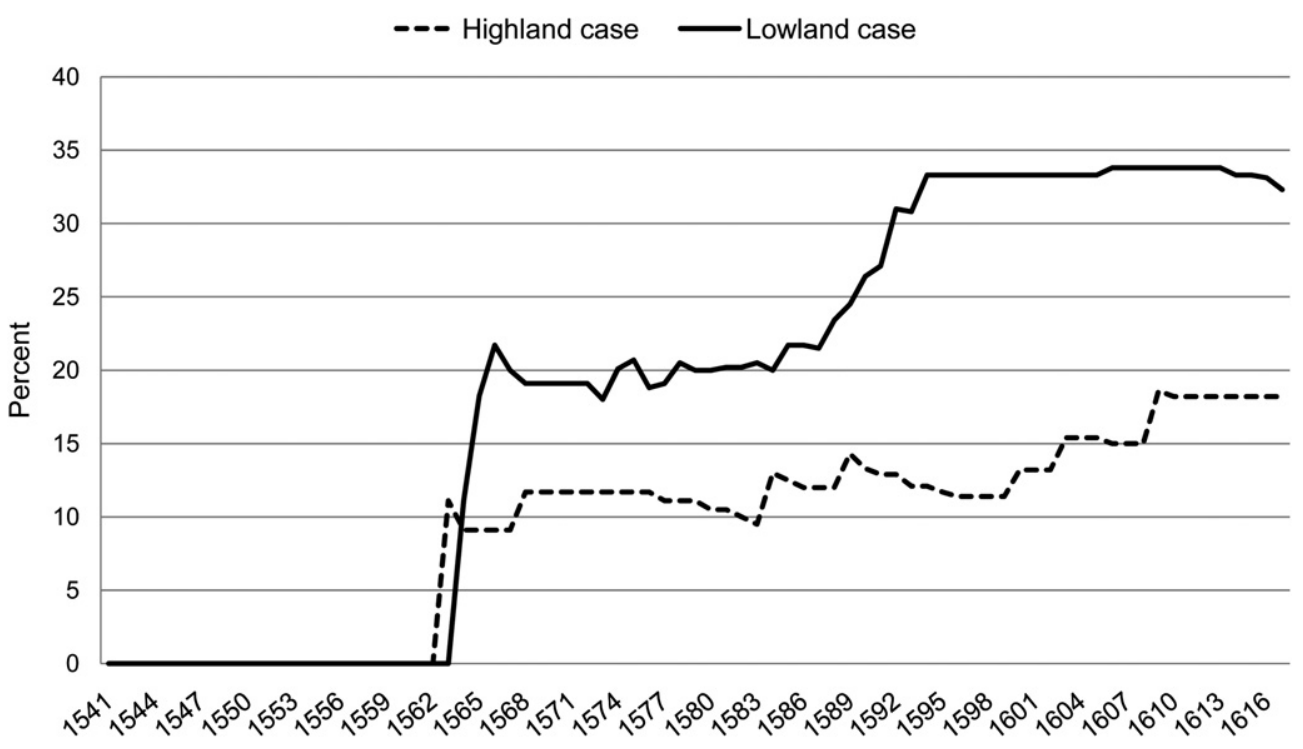

Fig. 4. Percentage of mercedes awarded that employ standardized units of distance.

For the highland case: [M]erced to Esteban Díaz del Valderrama, resident of Mexico City, of a sitio de estancia para ganado menor in the limits of the jurisdiction of the town of Hueypoxtla and one legua from Tezontlalpa and Ajoloapan. 50

Also, the highlands had only sheep estancias whereas the lowlands had both: 118 cattle estancias, which covered 206,146 ha; and 115 sheep estancias, which covered 89,240 ha. ${ }^{51}$ Each side of a cattle estancia extended $4.2 \mathrm{~km}$, or one legua legal; while each side of a sheep estancia was only $2.7 \mathrm{~km}$, just over one-half of a legua legal. In both cases, as the viceroys awarded more estancias in a particular area, the surveyors had to employ more and greater units of distance to describe the local land ownership. But because cattle estancias were larger, the distances used in cattle areas tended to be longer than in sheep areas. Again, grants for the lowlands and highlands illustrate the point:

For the lowland case: [T]wo sitios de estancia para ganado mayor to Nicolás de Salazar in the limits of the jurisdiction of the city of Vera Cruz, ....one....four leguas north of the said city and one [legua] from Estancia Santa Fe; and towards the south, little more than one legua separate it from the said Jamapa River; and towards the west is the ranch named San Josefe. ${ }^{52}$

For the highland case: [M]erced to Gregorio de Soto of a sitio de estancia para ganado menor in the limits of the jurisdiction of the town of Tezcatepec....bordered to the west by the lands of the said Gregorio de Soto, two leguas from the pueblo Santa María. ${ }^{53}$

\section{Directionals}

Standardized directional elements indicate relative position in a pre-conceived spatial framework. Examples include the cardinal directions of north, south, east, and west - norte, sur, este, and oeste in Spanish. In sixteenth-century New Spain more colloquial phrases provided synonyms for those directionals: donde sale el sol, or where the sun comes out, to indicate east; and poniente or donde pone el sol, meaning where the sun sets, to indicate west. ${ }^{54}$

Despite the obvious utility of directionals for describing an estancia's location, surveyors in both the highland and lowland cases adopted them only gradually. By 1556 in the lowlands surveyors had described the locations of the first six estancias with no use of directionals whatsoever. Likewise, in the highlands by 1559 surveyors had specified the locations of the first four estancias without using directionals (Fig. 5). The earliest surveyors to employ directionals tended to do so sparingly and as often with regard to the morphology of natural landscape features as to the morphology of the estancias. As an illustration, in the highlands in 1593 a surveyor recorded an estancia's proposed site as being 'in a plain that runs from north to south, near a small depression filled with water and some cherry trees, and in the vicinity of a number of wild maguey plants. 55

The highlands retained a nearly consistent $10-20 \%$ lead over the lowlands in the frequency that directionals appear in their respective surveys. The far fewer mercedes in the highland case may explain some of this difference because a low number of data points can yield a downwardly or upwardly skewed trend. As mentioned, directionals often relate to natural landscape features, and the undulating terrain of the highlands offered surveyors more topographical features on which to base a directional. For example, a survey from the highlands describes an estancia sited near 'two mountains that run east to west....at one place one of the ridge tops runs north to south....and the two plots of farmland are at the foot of a mountain in a ravine that runs north to south. ${ }^{56}$ Finally, proximity to Mexico City may have encouraged surveyors to adhere more closely to the viceregal ordinances that stipulated square estancias oriented to the cardinal directions.

\footnotetext{
50 AGN Tierras Vol. 2704, exp. 30, ff. 253v.-254.

51 Hunter, Methodologies for reconstructing a pastoral landscape (note 6); Sluyter, Colonialism and Landscape (note 6), $108-115$.

52 AGN Mercedes Vol. 19, ff. 81-v.

53 AGN Mercedes Vol. 23, ff. 113-v.

54 See for example AGN Mercedes Vol. 10, ff. 61-v., Vol. 12, f. 56v., Vol. 14, ff. 125-126, Vol. 19, f. 30.

55 AGN Mercedes Vol. 18, ff. 278v. -279.

56 AGN Mercedes Vol. 23, ff. 87v. -88 .
} 


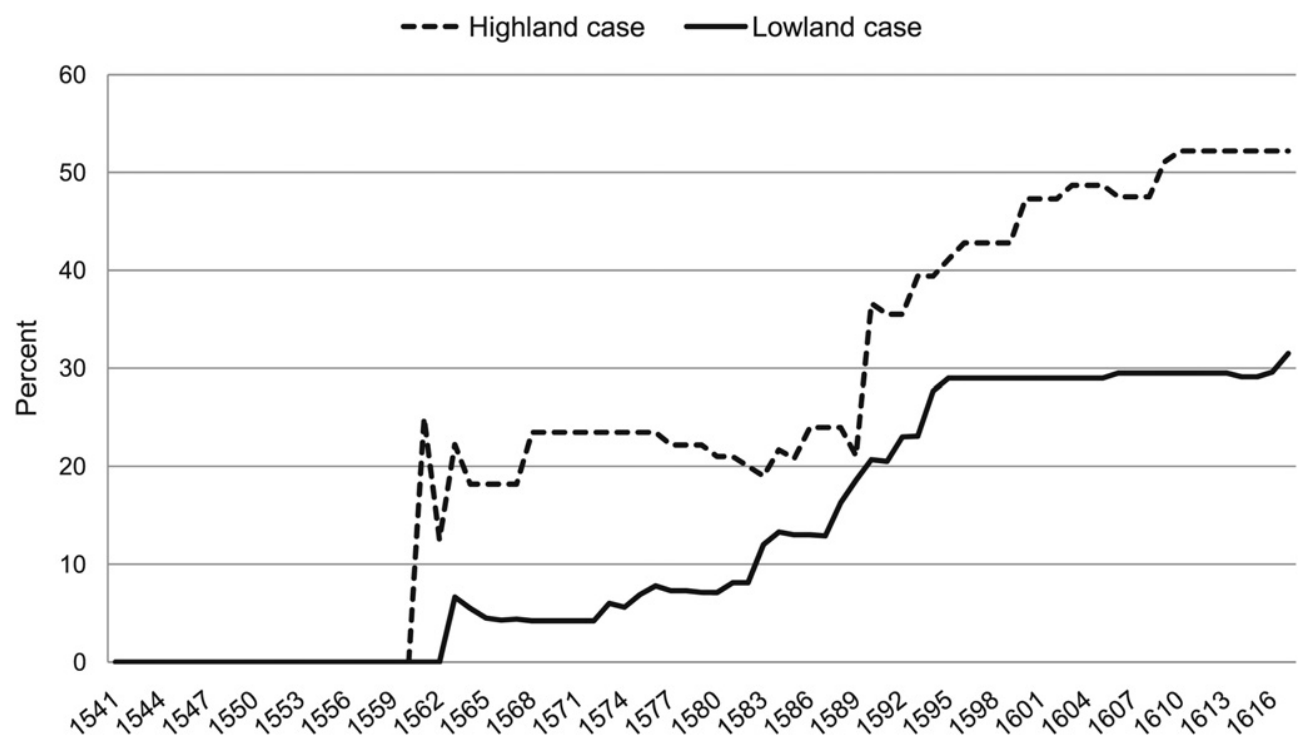

Fig. 5. Percentage of mercedes awarded that employ directionals.

Despite those ordinances, not until the 1580s did a trickle of references to directionals become a steady flow in both highlands and lowlands (Fig. 5). Those congruent rises may have resulted from an increased pace of colonization: more complete spatial colonization of the colony's core in conjunction with expansion along its periphery created more colonial territory through the construction of new landmarks and a greater awareness of native ones, both of which provided fixed points from which to estimate direction. Pre-Hispanic ruins and pyramids, natives' homes and agricultural fields, and so on gradually fell under the gaze of surveyors. $^{57}$ In 1586 in the highlands one perceptive surveyor observed that a site for an estancia was 'on a high, rocky hill to the right of a rock pile that appears to be an ancient pyramid. ${ }^{58}$

The directions that surveyors established with these and other landmarks bestowed colonists with more spatial knowledge, which in turn allowed them to create more colonial territory using distances and directions through a positive feedback loop. A prime example of this process concerns neighboring properties. Every estancia presented four conceptual sides by which to adjoin four more estancias. Those four estancias would then present 12 sides that surveyors could reference to site future estancias. Perhaps underscoring this point, of the 47 estancias awarded in the highlands only four appear not to have bordered any other estancia. ${ }^{59}$

\section{Borders}

Content analysis of textual surveys with regard to estancia borders poses more difficulties of data interpretation than for distances or directionals. The basic issue involves intent: did a particular surveyor intend to define a geometric object with distinct borders or simply describe the prominent linear characteristics of a particular site? In some instances the surveyor clearly intended to establish a border, such as when neighboring properties abutted one or more sides of the estancia. These references are often straightforward, such as in this survey from the lowlands that notes the 'southern part borders the lands of Pedro de Herrera and the northern part the lands of Agustín de Villanueva. ${ }^{60}$ But in the majority of surveys borders arise only incidentally during the general description of a site, which creates ambiguity over intent. A typical example of such an incidental description of borders involves an estancia 'on a hill between two ravines. ${ }^{, 61}$ It remains unclear whether the surveyor noted the ravines to establish two natural borders, or merely to reference prominent landmarks to locate the estancia as a whole.

Reducing that ambiguity as much as possible requires consideration of the types of landscape features that surveyors used to denote the location of estancia borders, including point features, linear features, and shared property lines. Point features included watering holes, rock piles, springs, precolonial rock pyramids, and so on. Because point features lack significant spatial extent they served as poor markers for the border of a parcel of land as sizeable as an estancia. For instance, in 1584 a surveyor in the highlands described an estancia that rested 'on the western skirts of a hill called Aranda next to an old waterhole. ${ }^{62}$ Presumably the grantee intended to keep his sheep either eastward or westward of the watering hole, although no defined borders appear to have restricted their range northward or southward. In the highland case, most of the estancias coincided with waterholes. $^{63}$

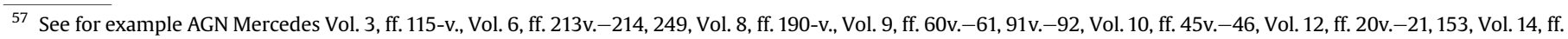
$161 \mathrm{v} .-162 \mathrm{v} .$, Vol. 20, ff. 22-23v.

58 AGN Mercedes Vol. 12, ff. 209-v.

59 Hunter, Methodologies for reconstructing a pastoral landscape (note 6).

60 AGN Mercedes Vol. 33, ff. 115v.-116v.

61 AGN Mercedes Vol. 13, ff. 41-v.

62 AGN Mercedes Vol. 12, f. 57.

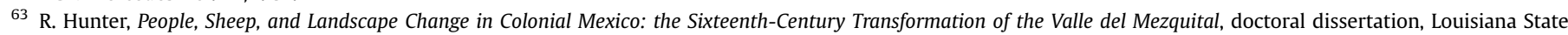
University, 2009, 130.
} 


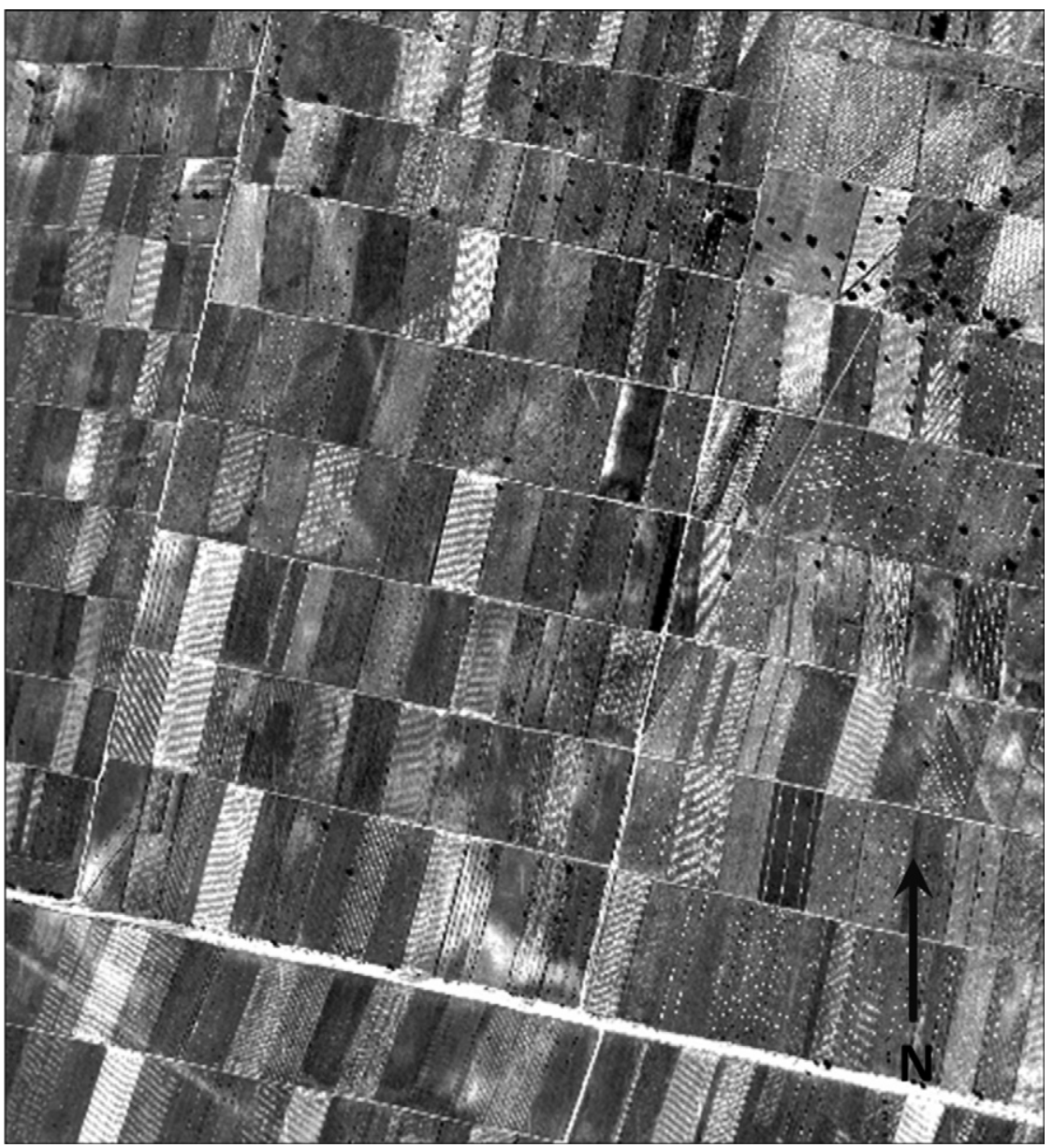

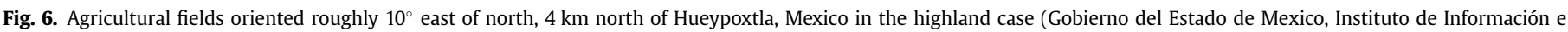
Investigación Geográfica, Estadística y Catastral, 2000. 1:20,000 digital orthophotographs).

In contrast, linear landscape features such as streams and roads can better define estancia borders. In the highlands in 1561 a surveyor described the future site of an estancia as sitting in a plain next to a stream that flows northwest. ${ }^{64}$ Local people could probably have identified the stream, yet it may have remained an open question, as it does today, exactly which side of the estancia bordered the stream. Royal highways (camino reales), secondary roads, and footpaths frequently appear in the surveys as the borders of land parcels. ${ }^{65}$ Their visibility, accessibility, length, and relative linearity must have made them ideal landscape features to form the borders of estancias. Where colonial spatial knowledge was limited, such as in newly colonized areas, transportation routes provided much needed borders to spatially anchor estancias. A 1541 survey for the first known estancia in the lowlands and a 1544 survey for the second known estancia in the highlands both draw upon roads to define one of their sides. ${ }^{66}$

In theory, an estancia awarded adjacent to a pre-existing estancia or plot of farmland would have exhibited at least one straight, well defined border, but despite the de jure squares de facto estancia borders deviated in response to the characteristics of a particular landscape. ${ }^{67}$ Sometimes those characteristics involved putatively natural features such as streams. For example, if a winding stream formed that parcel's eastern border, then the estancia that bordered it to the east would have had the same stream as its western border. At other times those characteristics involved precolonial cultural features. In precolonial Mexico some agriculturalists oriented their field boundaries to between $15^{\circ}$ and $18^{\circ}$ east of north. ${ }^{68}$ That orientation aligned with the point on the horizon where the sun rose at the onset of the rainy season, signaling the moment to sow the land. In places, those precolonial field boundaries persist 'even in the numerous cases where Spanish surveys of the late sixteenth and early seventeenth centuries described the land as empty, vacant, untilled, or abandoned, and where the survey parcels were described as oriented to the cardinal directions. ${ }^{69}$ That persistence certainly also applies to the area of the highland case, although not to the lowland case because of

\footnotetext{
64 AGN Mercedes Vol. 5, ff. 253-v.

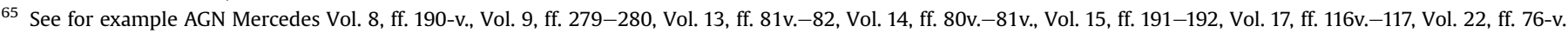

66 ANX Protocolo Vol. 1600-1608, f. 414; AGN Mercedes Vol. 2, f. 321.

67 Gibson, The Aztecs Under Spanish Rule (note 31), 276; Hunter, Methodologies for reconstructing a pastoral landscape (note 6).

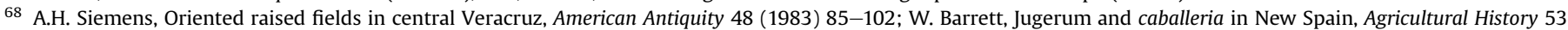
(1979) 423-437.

69 Barrett, Jugerum and caballeria in New Spain (note 68), 426.
} 
the much greater population decline in the lowlands during the sixteenth century (Fig. 6). ${ }^{70}$ Presumably, in cases where native population and precolonial field patterns persisted, the orientation of those field boundaries came to define the cardinal directions so that while the boundaries did not orient to the cardinal directions they were consistent. In cases that underwent greater native depopulation and field abandonment, determination of cardinal directions relied on surveyors estimating based on observation of the position of the sun, with the result that the azimuths of estancia boundaries varied greatly even though some might in fact orient to the cardinal directions.

The borders that surveys often described do not appear to have represented surrogate fences, as if point features could ever be, but rather visual cues for a shepherd about the general limits of his particular estancia. Any point or linear landscape feature would have sufficed as a landmark for a shepherd not to lead his animals past. The nuances of livestock herbivory also have relevance when considering estancia borders. To some degree, every rangeland has a heterogeneous spatial distribution of forage and surface waters. In a given range, livestock usually graze one or a few plant species preferentially, and only graze the least palatable plant species during drought conditions. ${ }^{71}$ Moreover, grazing animals possess a spatial memory that allows them to return to their preferred resource patches. ${ }^{72}$ Consequently, the places livestock visit for forage and drinking water - and the trails that connect these places - support the livestock nearly $100 \%$ of the time. ${ }^{73}$ If an estancia's center encompassed the parcel's most palatable forage, and the margins the least palatable, then the borders along the margins would have been of lesser importance because the livestock approached them less frequently than the center. If an estancia had rather homogeneous floristics, however, and the livestock grazed the parcel somewhat uniformly, then shepherding the animals within the visual cues of the border would have been a more critical task.

In the first few decades of colonization the relative openness of the rangelands, amplified by the steep decline in the native population, appears to have negated the need for strictly defined borders. Around the turn of the seventeenth century, as certain areas became congested with titled properties and landholders tried to maintain exclusive access to their pastures, locational generality of borders yielded to far more specificity. ${ }^{74}$ By 1609 in the highlands the survey descriptions had lengthened considerably in order to more precisely specify borders.

....to the south of a low hill that runs from east to west that passes a mountain called Aranda, which runs to the east to meet an estancia owned by Juan Francisco. And at the summit of Aranda there is an estancia owned by Bernardino de Estrada and the one owned by Juan Francisco. Furthermore, they say the estancia in question falls between two other estancias owned by Bernardino de Estrada on a low hill that forms the aforementioned hill, next to the road that comes from Actopan to this estancia on the left-hand side of the hill, about a musket shot from two small boundary stones....The western and eastern parts of the estancia adjoin two sheep estancias of the aforementioned Bernardino de Estrada, and to the south the large canyon of Zacacalco where the aforementioned Bernardino de Estrada has two estancias and four plots of agricultural land. And the northern part comes to a large stream that is between this estancia and another called San Pedro. ${ }^{75}$

Such longer textual surveys that emphasized borders signaled a transition towards the creation of territory that had not only location - but position. An object's position can be understood as the interplay of two spatial variables: its location (centroid) and the orientation of its axes. ${ }^{76}$ Establishing an estancia's location sufficed for rapidly creating and distributing territory to be incorporated into the colonial landholding regime. Yet as the sixteenth century closed the primary role of surveyors transitioned from participants in the creation of colonial territory to the administrators of the territory that previous generations of surveyors helped create decades earlier. For seventeenth-century surveyors to contribute to the administration of territory - its transfer, partition, and so on they had to be able to define a parcel's position. Tasked with defining a position meant that the ability to simply read the landscape was no longer sufficient; one had to be trained in the methods and instruments of the surveying profession.

\section{Conclusion}

In sixteenth-century New Spain, as in other incipient colonies, the spatial knowledge that emanated from the centralized state bureaucracy was alone insufficient to create territory. Territory came into being through the local interactions of peoples and places that modulated the state's attempt to spatially order the colony. Imperial cadastral abstractions became concrete in both landscape and archive as grantees, surveyors, and other actors went into the field to create an archive of textual surveys. As landscape and archive came into being they further modulated the process. Different environments, precolonial settlement patterns, types of grants, and individual surveyors and their social networks were all central to that process of territorial co-construction, as demonstrated through the contrasts between the highland and lowland cases.

Despite viceregal ordinances intended to make the act of surveying uniform, content analysis of surveys reveals how such coconstruction led to distinctive local surveying practices. In the precolonial and colonial eras the highlands had a much denser population than the lowlands, which provided the surveyors with a landscape replete with suitable cultural and topographical landmarks on which to base directionals. Consequently, the highland case has a consistently higher percentage of surveys that employ directionals than the lowland case. Distance, however, was a much more useful surveying element in the lowlands where surveyors sited cattle estancias widely over the relatively flat terrain. Cabeceras in the lowlands were also more widely distributed than in the highlands, which required surveyors to estimate distances up to six leagues. Distances were apparently less important to surveyors in

\footnotetext{
70 Sluyter, Colonialism and Landscape (note 6).

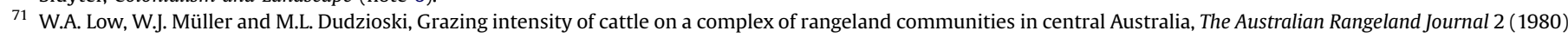

76-82; A.W. Illius and A.G. O'Connor, On the relevance of nonequilibrium concepts to arid and semiarid grazing systems, Ecological Applications 9 (1999) $798-813$.

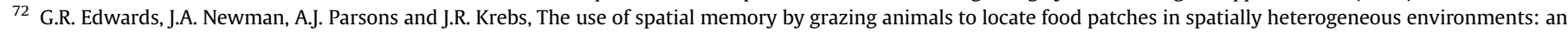
example with sheep, Applied Animal Behaviour Science 50 (1996) 147-160.

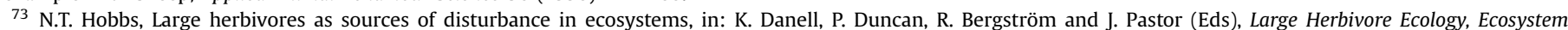
Dynamics and Conservation, Cambridge, 2006, 261-288.

74 Melville, A Plague of Sheep (note 14), 160; Hunter, Methodologies for reconstructing a pastoral landscape (note 6).

75 AGN Mercedes Vol. 26, ff. 161v.-162v.

76 A. Galton, Qualitative Spatial Change, Oxford, 2000, 156-157.
} 
the highlands, where smaller sheep estancias crowded each other in the elevational zones that ran between the cold, dry mountaintops and the humid cultivated fields. The dense precolonial settlement pattern in the highlands, reflected in the area's clustered cabeceras, further mitigated the need for surveyors to estimate distances greater than two leagues. In contrast to the other surveying elements, the ways surveyors defined estancia borders represent an aspect of territorial co-construction that unfolded similarly in both cases. Surveyors in the highlands and the lowlands drew upon point and linear features as well as neighboring properties to define borders. A possible difference, in form if not in function, may have been that precolonial field patterns influenced borders more often in the highlands. By the turn of the seventeenth century the surveys' descriptions of borders in both cases had lengthened considerably as some areas became congested with titled properties, and land owners strived to maintain exclusive access to their ranges.

Reconstruction of the biographies of the surveyors, as far as possible given the sources, reveals a social group that had some similar and some different motivations than the encomenderos and central state bureaucracy. Like the colonial state, the surveyors and their social networks of landed gentry sought to create legible territory through grants and surveys of land, rather different than the encomenderos motivated by control of tribute and labor. Like the encomenderos, however, the surveyors were enmeshed in local relationships and the realities of specific places. By the close of the granting period in the 1620 s their descendants and other social elites were acquiring the collections of mercedes that provided the legal basis for the entailed estates that dominated the rural spatial order until the agrarian reforms of the 1920s - the haciendas. Partitioning the hacienda lands again required local actors, the state bureaucracy, and specific landscapes to interact in a process of territorial co-construction. As Raymond Craib remarks on this process, the continual reformulation of knowledge in the field meant that what constituted knowledge did not necessarily precede its application; theorization and practice proceeded together. ${ }^{, 77}$

The same methodology could be applied to better understand the initial colonization of other places in the Americas. Such understanding demystifies the process through which colonial territories came into being, not only through the imperial imposition of abstract cartographies and grids from the center of power but also on the periphery through the contingencies of local actors and particular environments.

\section{Acknowledgements}

The authors would like to thank the staff of the Archivo General de la Nación in Mexico City for their dedicated service, and the three anonymous reviewers for their conscientious comments.

77 Craib, The archive in the field (note 7), 420. 